\title{
MINERAL TAXATION
}

\author{
MURRAY F. MACKINTOSH*
}

In these times of rapidly escalating prices for resources, the provinces of Western Canada have turned their attention to extracting from the resource industry a higher return for the citizens in an attempt to provide for the future when the resources are near depletion. This phenomenon is especially noticeable in Alberta. In this article Mr. Mackintosh discusses mineral taxation laws in Alberta and compares them with the corresponding laws of Saskatchewan and British Columbia. The author discusses the constitutionality and interpretation of the new mineral taxation laws and raises some specific problems in applying the legislation.

\section{INTRODUCTION}

This discussion relates to the recent changes in the mineral taxation legislation in Alberta, British Columbia and Saskatchewan. Manitoba has been omitted, not because there may not be problem areas worth of comment but simply on the basis of the time at our disposal.

\section{THE STATUS QUO BEFORE THE DELUGE}

First I will go back and consider the situation in Alberta under the 1970 Act, with a comparative look at the situation in Saskatchewan and British Columbia.

1. Alberta - The Mineral Taxation Act, R.S.A. 1970, c. 236

There were two taxes imposed by this Act:

(1) Mineral acreage tax $-a$ tax of a certain amount per acre against the owner registered under the Land Titles Act of any mineral rights regardless of the value or nature of the mineral rights (prescribed by the Lieutenant Governor in Council at a rate not to exceed five cents per acre): s. 4 .

(2) Producing area tax - a tax based on "fair actual value" of the "principal mineral" in a "producing area" according to rules of assessment set forth in the Act: s. 8.

Under the regulations the method of calculating the producing area tax involved using barrels produced and well-head price as multipliers. The question had arisen earlier, in 1952, under a similar Saskatchewan Act as to what was being taxed, minerals in place or minerals produced? The answer was given in the Supreme Court of Canada in C.P.R. v. A.G. for Saskatchewan. ${ }^{1}$

It may be useful to review this case because it establishes the rules with respect to the constitutional validity of both types of tax. By virtue of the Mineral Taxation Act, R.S.S. 1948, c. 24 and amendments the Province of Saskatchewan purported to impose an annual tax on each owner of minerals within the province regardless of whether minerals were or were not present

- Solicitor, Hudson's Bay Oil and Gas Company Limited, Calgary, Alberta.

1 [1952] 2 S.C.R. 231. 
within, upon or under the land. "Owner" was defined as a person registered in a land titles office as the owner of any minerals. "Mineral" means the rights existing in any person by virtue of a certificate of title to work, win and carry away any mineral or minerals within, upon or under the area described in the certificate of title, and also any mineral or minerals within, upon or under any land.

The Act provided that in a "non-producing area", the tax would be at the rate of three cents per acre of land. The Lieutenant Governor was given the power to declare any area in the province a "producing area" and provision was made for the assessment, at their fair value, of minerals in a producing area. Until an assessment was made the owner was liable to pay at the rate of 50 cents per acre and fraction thereof of land in such an area. Following an assessment the owner would be liable to pay a tax at the rate prescribed from time to time by the Lieutenant Governor in Council but not exceeding ten mills on the dollar of the assessed value of the minerals. Non-payment of the tax resulted in forfeiture of the minerals to the Crown.

It was decided by the full court, the Chief Justice dissenting, that each of the three taxes is a land tax, is clearly direct taxation and is not imposed with the intention that it should be passed on to someone else.

Counsel for the appellant railway Company had advanced the argument, among others, that the tax is imposed upon the owner in respect of mineral rights and in respect of the minerals themselves. A tax thus imposed is analogous to a tax on the producer of a commodity in respect of a commodity and such a tax is indirect taxation: Bank of Toronto v. Lambe. ${ }^{2}$ The interest in land in respect of which the tax in question is imposed is the right to extract or produce from the land a commodity which will be the subject of commercial transactions. Such an interest in land cannot be considered as falling within the well recognized class of land taxes that have always been regarded as direct taxes.

The court, however, would not accept the argument. Kerwin J., speaking for himself and for Taschereau, Cartwright and Fauteux JJ., concluded that this is not a tax on production and approved the statement of O'Halloran J. which was adopted, at page 115, by Lord Greene, speaking for the Judicial Committee of the Privy Council in A.G. of B.C. v. Esquimalt and Nanaimo Railway Co.:"

Because land bears a tax which is measured by the reflected value of its products is no reason to say that the tax on the land is a colourable tax on its products, and that such a tax is not in truth a tax on the land itself.

Rand J. stated, in part:4

Section 7 directs an assessment each year "at their fair value" of all minerals "within, upon or under any parcel of land situated within a producing area and within the boundaries of which land minerals are then being produced or to the knowledge of the assessor have at any time been produced and shall prepare an assessment roll in which shall be set out, as accurately as may be, a brief description of each such parcel of land, a brief description of the minerals assessed, the names and addresses of the owners of the minerals and the assessed value thereof." Subsection (2) authorizes him to resort to all available information pertinent to that value. ...

The appellants are the owners of minerals both severed and unsevered in title from the fee simple, and have brought this action for declaration that the statute is ultra vires; and the narrow question presented is whether the annual tax of minerals in situ, as a component of the soil, having a special discrete value to be realized upon some manner

2 (1887) 12 A.C. 575.

3 [1950] A.C. 87.

1 Supra, n. 1 at 249-250. 
of removal from the soil, is direct taxation within the meaning of these words as used in head 2 of Section 92 of the British North America Act."

Section 92 (2) of the British North America Act reads:

92. In each province the Legislature may exclusively make laws in relation to matters coming within the classes of subjects next hereinafter enumerated; that is to say,

2. Direct taxation within the province in order to the raising of a revenue for provincial purposes.

\section{Rand J. continued: ${ }^{5}$}

That, for the purposes of a land tax, the assessed value of land can reflect the value of its products, such as timber, even though the timber represents substantially the entire value, was laid down by the Judicial Committee in the case of A.G. of British Columbia v. Esquimalt \& Nanaimo Railway Company. This Court had held the proposed imposts to be a tax in substance on the timber as and when severed, but that view was rejected.

I can see no difference, for this purpose, between the reflected value of a "growing" product and one, such as mineral, of a somewhat desparate character and of a limited quantity or existence: they are all, in contemplation of law, part of the soil. . . .

The tax, at the moment of imposition, is in fact against land; it is an annual impost; the charge securing it is limited to land; and it is not an item related to or recognized as reflected in the cluster of charges intended and expected to be recouped in the price of the marketed commodity. It is of the nature of a fixed asset tax rather than a transaction tax; and it is therefore direct. That being so in the case of the tax based on an annual assessment of value, it is much more clearly so in the cases of the flat acreage rates."

One succinct comment of Kellock J. will serve to conclude this reference to the C.P.R. case: ${ }^{6}$

It is well settled that ownership of mineral in situ as an interest in land may be severed from ownership of the "surface" rights. There is in principle no reason, in my opinion, why, although taxation in respect of the unity of ownership is direct, and taxation of the "surface" rights is also direct, taxation in respect of the mineral rights should be regarded in any other light. The tax here in question is an annual levy, payable notwithstanding that the mineral never becomes a commodity. Such a tax, in my opinion, is simply a land tax.

In result, we are left in little doubt that, if a tax falls generally within the definition of the "producing area" tax, it will be found to be intra vires of a provincial legislature on the authority of the 1952 C.P.R. decision, and a mineral acreage tax will, of course, also be found to be intra vires of the province.

\section{Saskatchewan - The Mineral Taxation Act, R.S.S. 1965, c. 64}

This Act is similar to the Alberta Act, and is substantially similar to the Saskatchewan Act of 1948 discussed above in the 1952 C.P.R. case.

(1) A mineral area tax was prescribed at 20 cents per acre (s. 3 ), and a second tax was payable, based on the value of minerals.

Either

(2) Taxation in producing areas - based on an assessment of the fair value of mineral, at a rate not exceeding 10 mills on the dollar: s. 7 .

Or

(3) Taxation in producing tracts - based on the value of a principal mineral determined annually by the Minister, at a rate not exceeding 10 mills on the dollar: s. 25.

SId. at $250-252$.

-Id. at 253. 
3. British Columbia - The Mineral Property Taxation Act, R.S.B.C. 1960, c. 245

This was a rather brief Act which was dissimilar to the Alberta and Saskatchewan Acts in that it did not provide for a mineral acreage tax, but was similar in that it provided for a producing area tax, based on an assessment at fair value of the minerals and at a rate not to exceed 10 per cent: s. 4 .

There was also a provision for abatement of tax to the extent of Crown Royalty paid on the mineral production from the parcel of land which was taxed: s. 12.

\section{THE CHANGES MADE IN THE LAST THREE YEARS}

\section{Alberta}

In press releases made in April and July of 1972 The Alberta Government announced a "Natural Resources Revenue Plan relating to Crude Oil". This plan provided for a new Mineral Taxation Act which would assess and tax on an ad valorem basis both freehold owners and the holders of Crown rights, and provided for an election by holders of Crown petroleum and natural gas rights to amend their leases having maximum royalty rates to a new (higher) royalty schedule and be exempt from the new tax, or to retain their leases unamended as to royalty and pay the tax in addition.

(1) The Mineral Taxation Act, S.A. 1972, c. 67

The definition of "owner" in s. 1(i) was broadened to include the holder of Crown petroleum and natural gas rights under the Mines and Minerals Act. ${ }^{7}$ The only tax provided for was an ad valorem tax on the assessed value of the mineral at a rate to be set by the Lieutenant Governor in Council. This act amended The Mineral Taxation Act, $1970,{ }^{8}$ by providing that it would not apply to the 1973 and subsequent taxation years.

However, on October 4, 1973 Premier Lougheed announced that, as a result of the Federal Government's Oil Export Tax, the existing Alberta Oil Revenue Plan would be of no further effect at the end of 1973. In result, then, this Act applied only to the 1973 taxation year.

With the reversal in policy by the Alberta Government it became clear that maximum royalty limits would be eliminated on all Crown Leases, and a new Mineral Taxation Act would be required for freehold minerals.

(2) The Freehold Mineral Taxation Act, S.A. 1973, c. 89

The tax imposed by this Act is an ad valorem tax against an owner of a mineral, registered under the Land Titles Act, ${ }^{\circ}$ based on assessed value at such mill rate as is prescribed by the Lieutenant Governor in Council from time to time: ss. $14,1(j)$.

\section{Saskatchewan}

We are still dealing today with the Mineral Taxation Act, ${ }^{10}$ with some amendments as follows:

(1) Amending Act S.S. 1972 , c. 79 - eliminated the ceiling of 10 mills on the dollar from the tax on producing tracts: s. 25 .

T R.S.A. 1970, c. 238.

8 R.S.A. 1970, c. 236.

O R.S.A. 1970 , c. 198.

10 R.S.S. 1985 , c. 64. 
(2) Amendment in the Bill 42 Legislation (1973) ${ }^{11}$ - increased the mineral acreage tax from 20 cents per acre to 50 cents per acre: s. 3 .

\section{British Columbia}

Effective December 31, 1973, the Mineral Property Taxation Act ${ }^{12}$ was repealed.

A new Act, the Mineral Land Tax Act, S.B.C. 1973, c. 53, has been in force since June 15, 1973.

Under this Act there is a mineral acreage tax on total mineral land held at a sliding scale from 25 cents per acre, on tracts of less than 50,000 acres, to $\$ 1.00$ per acre on tracts of one million acres or more: s. 4 .

There is also a mineral acreage tax in a production area of $\$ 2.00$ per acre and an ad valorem tax on the assessed value of designated mineral land in a production area or in a production tract: s. 5. But where tax is payable under s. 5, no tax is payable under s. 4 on the same mineral land or on the same designated mineral land.

Consequential amendments to The Taxation Act $^{13}$ have eliminated the definition of "mineral", which excluded petroleum and natural gas. While Crown lands are specifically exempt under s. 24(i) of The Taxation Act, the liability of freehold minerals to tax would appear to be left open.

\section{WHAT IS SO DIFFERENT ABOUT TAXING STATUTES?}

P. St. J. Langan, editor of the 12th edition of Maxwell on The Interpretation of Statutes has the following to say: ${ }^{14}$

\section{ENCROACHMENT ON RIGHTS}

Statutes which encroach on the rights of the subject, whether as regards person or property, are subject to a strict construction in the same way as Penal Acts. It is a recognized rule that they should be interpreted, if possible, so as to respect such rights and if there is any ambiguity, the construction which is in favour of the freedom of the individual should be adopted. One aspect of this approach to legislation is the presumption [emphasis added] that a statute does not retrospectively abrogate vested rights; another is the presumption [emphasis added] that proprietary rights are not taken away without provision being made for compensation.

The editor continued: 15

Statutes which impose pecuniary burdens are subject to the same rule of strict construction. It is a well-settled rule of law that all charges upon the subject must be imposed by clear and unambiguous language, because in some degree they operate as penalties: the subject is not to be taxed unless the language of the statute clearly imposes the obligation, and language must not be strained in order to tax a transaction which, had the legislature thought of it, would have been covered by appropriate words.

The judiciary have also made several important pronouncements on taxation statutes, some of which are as follows:

11 The Oil and Gas Conservation Stabilization and Development Act, 1973, Bill 42.

12 R.S.B.C. 1960 , c. 245.

18 R.S.B.C. 1960 , c. 376.

14 Maxwell on the Interpretation of Statutes (12th ed. Langan 1969) at 251.

$15 \mathrm{Id}$. at 256. 
In a taxing Act, one has to look merely at what is clearly said. There is no room for any intendment. There is no equity about a tax. There is no presumption as to a tax. Nothing is to be read in, nothing is to be implied. One can only look fairly at the language used: per Rowlatt J., Cape Brandy Syndicate v. I.R.C. [1921] I K.B. 64 at 71, approved by Viscount Simon L.C. in Canadian Eagle Oil Co., Ltd. v. R. [1946] A.C. 119.

I am not at all sure that, in a case of this kind - a fiscal case form is not amply sufficient; because, as I understand the principle of all fiscal legislation, it is this: if the person sought to be taxed comes within the letter of the law he must be taxed, however great the hardship may appear to the judicial mind to be. On the other hand, if the Crown, seeking to recover the tax, cannot bring the subject within the letter of the law the subject is free, however apparently within the spirit of the law the case might otherwise appear to be. In other words, if there be admissible, in any statute, what is called an equitable construction, certainly such a construction is not admissible in a taxing statute, where you simply adhere to the words of the statute: per Lord Cairns in Partington v. Attorney-General (1869) L.R. 4 H.L. 100 at 122.

I see no reason why any special canons of construction should be applied to any Act of Parliament, and I know of no authority for saying that a taxing Act is to be construed differently from any other Act. The duty of the court is, in my opinion, in all cases the same, whether the Act to be construed relates to taxation or to any other subject, viz., to give effect to the intention of the legislature, as that intention is to be gathered from the language employed, having regard to the context in connection with which it is employed. The court must no doubt ascertain the subject matter to which the particular tax is by the statute intended to be applied, but when once that is ascertained, it is not open to the court to narrow or whittle down the operation of the Act by considerations of hardship or business convenience, or the like: per Lord Russell of Killowen C.J. in Attorney-General v. Carlton Bank [1899] 2 Q.B. 158 at 164.

\section{SPECIFIC PROBLEMS WITH THE LEGISLATION}

Most of these are probably best described as administrative or quasilegal problems, rather than as purely legal problems.

\section{Alberta - The Freehold Mineral Taxation Act, S.A. 1973, c. 89}

We should consider the sufficiency of the Assessment Roll under s. 7, and of the Assessment Notice under s. 10.

The first problem faced by an oil company tax department relates to identifying the land that is being taxed. Legal descriptions, which used to be provided on the assessment notice, are not being provided by the administration under the new Act. The assessment roll and the assessment notices contain a "property name" and a "production profile" which are related to the legal description but which are not full legal descriptions. Both documents contain the Certificate of Title number issued under the Land Titles Act. ${ }^{16}$ The first task of the taxpayer then is to check with his land records and annotate on his assessment notice the proper legal description so that he can be sure of his facts in making the decision whether or not he will apply to the Appeal Board under s. 11 for a revision of any of his assessments.

To any objection that there is an insufficiency of notice by virtue of lack of legal description, the Crown can reply, "What better legal description can there be than the reference to the number of the Certificate of Title?" We are probably left, then, simply with an example of the "hardship" or "[lack of] business convenience" referred to by Lord Russell of Killowan C.J. in the quotation above. 
Section $7(3)$ should be read together with the definition of "owner" and with s. 22.

With respect to a person who is registered as owner, under The Land Titles Act, of a specified undivided interest of less than the whole in a mineral right, consider what his tax liability would be.

On a strict construction does this provision in s. 22(1) extend to value or does s. 7 (1)(b) (iii) prevail? Surely the latter must prevail, but if it does then some ambiguity is created as to the extent to which s. 22(1) applies.

Another consideration is the taxpayer's entitlement to notices of assessment and taxation. Under s. 22(2) does each taxpayer get his own tax notice? Perhaps s. 15 is sufficient to assure this result.

What is the meaning of "nor affected by the agreement, order or other document setting out the arrangement in s. 8? The words "nor affected by" have a vagueness about them. How can a unit operator, for example, be sure that it is complying with s. 8(1)?

No problems with respect to the appeal procedure provided in sections 11 and 12 per se have come to my attention as yet.

In the area of the computational methods of the assessor, individual companies are facing problems where the assessor utilizes current commodity value in arriving at the fair actual value and the company holds a gas purchase contract with no provision for price redetermination.

The power under s. 14 of prescribing the mill rate is left with the Cabinet and there is no time limit. The result is an administrative problem with respect to forecasting and budgeting. There is no maximum mill rate as there was under the old Act so one does not even have a maximum figure to rely on.

Again, this is one of Lord Russell's "considerations of hardship or business convenience." Apropos to this imposition on the taxpayer are the apt words of the Taxation Section of the British Columbia Branch of the Canadian Bar Association in a brief to the Honourable Leo Nimsick, Minister of Mines and Petroleum Resources for British Columbia, on the Mineral Royalties Act, in part:

Unless taxpayers are able to measure the economic effects of revenue legislation with some degree of certainty, they are unable to make intelligent economic decisions ...

Liability for a tax or an equivalent charge should be explicit and ascertainable.

Any presumption that proprietary rights should not be taken away without provision for relinquishment under s. 25 is subject to "the prior consent of the Minister": s. 25(1).

2. Saskatchewan - Mineral Taxation Act, R.S.S. 1965, c. 65, as amended, up to and including the Bill 42 Legislation ${ }^{17}$ amendment.

By s. 3 of the Bill 42 amendment, the tax is increased from 20 cents per acre to 50 cents per acre. A question of interpretation arises under Part IV of the Bill 42 Act. There is a compulsory taking of oil and gas rights "in all producing tracts in Saskatchewan down to and including the producing zones". The deep rights are not vested in the Crown. Neither are potash and coal. Can the Crown continue to levy mineral acreage tax on the owners of the deep petroleum and natural gas rights and also on the owners of potash and coal? 
Section $3 A$ is the 1970 , c. 44 amendment which has not been proclaimed in force. Since the Bill 42 amendment has now increased the tax rate across the board to 50 cents per acre, s. $3 \mathrm{~A}$ presumably will never be proclaimed.

There have been no "producing areas" declared under s. 6. The exemption available to a taxpayer under s. 3(1) relates only to "land situated within a producing area." Therefore, lands which are taxed as "producing tracts" under s. 25 are also taxed under s. 3.

On the question of sufficiency of notice, Saskatchewan appears to be the only one of the three provinces which still requires that the Assessment Roll, under s. 8(1) and the Assessment Notice, under s. 12(2), shall include a description of each such parcel of land" and satisfies that requirement by including the legal description of the land.

The limit set in s. 25 on the mill rate - "not exceeding 10 mills on the dollar" - has been deleted by S.S. 1972 , c. 79.

Since there is no specific provision for relinquishment of mineral titles to the Crown, the forfeiture route may be followed. On the question of liability for arrears and penalties up until the time the forfeiture is complete, see s. 32 .

Note also that ss. 36 and 37 of the Bill 42 legislation provide, in the Minister's discretion, for the acquisition by the Minister, of minerals by way of purchase or surrender of leases of oil and gas rights.

The Legislative Assembly for Saskatchewan gave third reading on May 9, 1974, to Bill 129, an Act to amend The Mineral Taxation Act. The main effects of these amendments are:

(1) Subsection $3(3)$ is repealed and the result is that coal is now included as a mineral.

(2) A new subs. (6) is added to $s .3$ and the result is that a trust company holding lands for an owner that does not own more than 3,200 acres of minerals does not have to pay tax on that acreage.

(3) A new s. 5A is added which renders void certain transfers or agreements respecting minerals made on or after the tenth day of December, 1973.

(4) Certain other amendments affect potash and coal.

\section{British Columbia - The Mineral Land Tax Act, S.B.C. 1973, c. 53}

The question which arises is how this Act relates to The Taxation Act, ${ }^{18}$ as amended? $U p$ to the enactment of The Mineral Land Tax Act in 1973, the Taxation Act had a definition of "minerals" which excluded petroleum and natural gas. By the amendment contained in The Mineral Land Tax Act, however, the definition of "minerals" was repealed, and we are left with definitions of "land" and "property" as follows: ${ }^{19}$

(i) "land" includes land covered by water, and all quarries and substances in or under land;

(ii) "property" includes land and improvements . . . .

Under Part II (Taxation of Land and Improvements), s. 24 exempts from taxation "Iand and improvements thereon vested in or held by ... " the Crown, Federal or Provincial.

It seems the definition, assessment and charging sections are still broad enough to include freehold petroleum and natural gas rights. But the best

18 Supra, n. 13.

19 The Taxation Act, R.S.B.C. 1960 , c. 376, s. 2. 
information I have been able to obtain indicates that the government intends that freehold petroleum and natural gas rights will be taxed under the Mineral Land Tax Act, and The Taxation Act is not intended to cover resources other than timber. We had best let sleeping dogs lie.

Now, consider the Mineral Land Tax Act itself:

(1) Section 1. The definition of mineral land excludes Crown Land. The definition of owner is not restricted to a registered owner under the Land Registry Act.

(2) Section 4. The strict construction rule works a hardship on owners on the low end of an acreage range.

(3) Section 5. The result seems to be that if you pay tax under s. 5, you do not pay under s. 4 on the same land. But you will pay two taxes under s. 5 .

(4) Section 6. This section merely requires the administrator to provide an "assessment roll containing such information as the minister may prescribe." The assessment notice shall contain "the information contained in the . . . assessment roll." Surely, on the question of sufficiency of notice, this must represent the ultimate in convenience to the taxing authority and the ultimate in hardship and inconvenience to the taxpayer!

(5) Section 6. The interesting thing here is the definition of "owner". It includes a petroleum and natural gas lessee, and probably in some cases also a farmee who has earned an interest but not yet received the sublease. Therefore, the lessee and farmee would get the notice, too, and this is a happy result for the convenience of the taxpayers. Compare this section with s. $9(3)$.

(6) Section 14. As an alternative to forfeiture, consider "Surrender of Interest in Mineral Land Regulation", B.C. Reg. 46/74. This regulation contemplates a surrender by quit claim deed which is an instrument which is known to the land registry system of British Columbia.

As a further alternative consider an Act to Amend the Mineral Land Tax Act, S.B.C. 1973 , c. 130 , which adds a new s. 25 A providing for a surrender of mineral land on such terms as the Lieutenant-Governor in Council may prescribe.

\section{VI. "STANDARD FORM" CLAUSES}

The appendix lists certain clauses in agreements commonly in use. I am not aware of any changes in these clauses which will be necessitated by the changes in the mineral taxation legislation, but it will probably be worth while to keep these "standard forms" in mind critically when we are working with the amended statutes.

\section{APPENDIX “A”}

MODEL OIL AND GAS UNIT AGREEMENTS

(Mines Ministers' Conference, Edmonton, September, 1972)

\section{UNIT AGREEMENT}

1306. TAXES

Each Party shall be separately liable to the extent of its ownership for all taxes on Unitized Substances and with respect to the production or sale of Unitized Substances. A Working Interest Owner may, at any time and from time to time, pay said taxes on behalf of its Royalty Owner and deduct the amount of the payment from the Royalty Owner's royalty. Those taxes with respect to the 
production or sale of Unitized Substances shall be adjusted so that they are borne as if the basis of taxation was the allocation of Unitized Substances hereunder.

\section{RIGHT OF REDEMPTION}

A Working Interest Owner may, at any time and from time to time, with full rights of subrogation, redeem for its Royalty Owner any agreement for sale, mortgage, or other lien or encumbrance of any kind or nature affecting any interest in the Unit Area in the event of default of payment by the Royalty Owner and deduct the amount of any payment made hereunder from the Royalty Owner's royalty.

\section{UNIT OPERATING AGREEMENT}

\section{TAXES, RENTALS AND ROYALTIES}

Each Party shall pay or be responsible for the payment of all taxes (other than taxes on Unit Facilities which shall be paid by the Unit Operator for the Joint Account) rentals and royalties applicable to the Party's Working Interest in the respective Tracts and shall indemnify and save harmless all other Parties from all claims, suits, loss, costs, expenses and damages paid or incurred by them as a result of its failure to do so.

\section{CANADIAN ASSOCIATION OF PETROLEUM LANDMEN (1974 DRAFT) OPERATING PROCEDURE}

312 TAXES - Except as otherwise provided herein or in the Agreement, the Operator shall initially pay for the joint account all taxes (except income taxes) with respect to property held for the joint account. 